Indonesian Journal of Islamic Psychology

Volume 2. Number 2, December 2020 (p-ISSN: 2685-1482 e-ISSN 2714-7576)

website: http://e-journal.iainsalatiga.ac.id/index.php/ijip/index

\title{
Hipertensi Pada Karyawan Pabrik Kimia, Adakah Hubungan Dengan Beban Kerja? (Studi pada Karyawan Pabrik Kimia (PT X) di Karanganyar)
}

\author{
Amalia Nurazizah ${ }^{1}$, Ading Pradana ${ }^{2}$, Afani Nur Fauziyyah ${ }^{3}$ \\ ${ }^{123}$ Universitas Sebelas Maret Surakarta, Indonesia
}

\begin{abstract}
Hypertension is one of the number one causes of death globally. There are many risk factors for hypertension, one of which is stress that occurs through workload. The purpose of this study was to see if there was a relationship between workload and high blood pressure among employee of PT X. This study uses a quantitative research design with correlational quantitative research methods. The population in this study were all employees of PT X which amounted to 352 people. From this population, 52 samples were taken representing each department of PT. X This research was conducted using a cross sectional approach. The data analysis technique used the Chi Square Test. Based on the results of this study it was found that the workload factor did not have a significant relationship with high blood pressure (hypertension) in the employees of PT X (sig. $=0.610>0.05)$. The results of the study can be used as a consideration regarding the use of workload variables on high blood pressure and to conduct further studies to find other variables that have the potential to have a relationship with high blood pressure in employees.
\end{abstract}

Keywords: blood pressure; hypertension; workload; employees

\begin{abstract}
Abstrak
Hipertensi merupakan salah satu penyebab kematian nomor satu secara global. Terdapat banyak faktor risiko hipertensi, salah satunya ialah stres yang timbul melalui beban kerja. Tujuan penelitian ini untuk mengetahui apakah terdapat hubungan antara beban kerja dan tekanan darah tinggi pada karyawan PT X. Penelitian ini menggunakan desain penelitian kuantitatif dengan metode penelitian kuantitatif korelasional. Populasi dalam penelitian adalah seluruh karyawan PT X yang berjumlah 352 orang. Dari populasi tersebut, diambil sampel 52 orang yang mewakili masing-masing departemen PT X. Penelitian ini dilakukan dengan menggunakan pendekatan Cross Sectional. Teknik analisis data menggunakan Uji Chi Square. Berdasarkan hasil penelitian ini ditemukan bahwa faktor beban kerja tidak mempunyai hubungan yang bermakna dengan tekanan darah tinggi (hipertensi) pada karyawan PT X (sig. $=0,610>0,05$ ). Hasil penelitian dapat digunakan sebagai pertimbangan terkait penggunaan variabel beban kerja terhadap tekanan darah tinggi dan melakukan studi lebih lanjut guna mencari variabel lain yang berpotensi memiliki hubungan terhadap tekanan darah tinggi pada karyawan.
\end{abstract}

Kata Kunci: tekanan darah; hipertensi; beban kerja; karyawan

*Corresponding Author

amalianpsy@gmail.com 


\section{Amalia Nurazizah, Ading Pradana, Afani Nur Fauziyyah}

\section{Pendahuluan}

Hipertensi adalah masalah yang sedang dialami oleh seluruh dunia. Berdasarkan data WHO (2008), sebesar $40 \%$ penduduk usia dewasa menderita hipertensi. Prevalensi di Amerika sebesar 35\%, Eropa sebesar 41\%, dan Australia sebesar 31,8\%. Prevalensi hipertensi pada kawasan Asia Tenggara adalah sebesar 37\%, Thailand 34,2\%, Brunei Darussalam 34,4\%, Singapura 34,6\% dan Malaysia 38\% (Hestiningsih, 2012). Banyak negara saat ini, prevalensi hipertensi meningkat sejalan perubahan gaya hidup. Hipertensi sudah menjadi masalah kesehatan masyarakat dan akan menjadi masalah yang lebih besar jika tidak ditanggulangi, dimana hipertensi adalah salah satu penyebab kematian nomor satu secara global (Susilo, 2011).

Penelitian Kemenkesri dalam Riskesdas (2013) prevalensi hipertensi di Indonesia yang di dapat melalui pengukuran pada umur $\geq$ 18 tahun rata-rata $20 \%$ pada tiap provinsi, dan melalui hasil penelitian Riskesdas (2013), hipertensi menurut karakteristiknya didapat bahwa status pekerjaan juga dapat mempengaruhi terjadinya hipertensi dengan prevalensi sebesar $24,72 \%$.

PT X merupakan perusahaan industri kimia dan berbasis di Kabupaten Karanganyar, Jawa Tengah. Perusahaan tersebut merupakan penghasil produksi Ethanol, Acetic Acid, dan Ethyl Acetate. Berdasarkan wawancara yang dilakukan kepada salah satu staff bagian HRD, ditemukan bahwa terdapat kejadian hipertensi pada karyawan yang bekerja di PT X, kemudian staff tersebut menambahkan dengan banyaknya produk yang dihasilkan, karyawan yang bekerja di perusahaan tersebut memiliki target kerja yang harus dipenuhi dalam satu waktu tertentu. Aktivitas fisik yang dilakukan juga cukup banyak seperti berjalan dari tempat satu ke tempat lain dengan jarak yang cukup 
Amalia Nurazizah, Ading Pradana, Afani Nur Fauziyyah

jauh, mengangkat barang dan naik turun tangga gedung setiap hari. Oleh karena tuntutan target pekerjaan, karyawan diforsir untuk menyelesaikan pekerjaan tepat waktu ditambah dengan dengan kondisi perusahaan yang bising dan penuh tekanan, karyawan memiliki beban kerja yang dirasa cukup tinggi.

Tekanan darah tinggi atau hipertensi merupakan penyakit yang ditandai dengan peningkatan tekanan darah yang melebihi normal. Menurut Soeharto (2004) tekanan darah tinggi (hipertensi) adalah keadaan dimana seseorang mengalami peningkatan tekanan darah di atas normal atau kronis (dalam waktu yang lama). Hipertensi sering mengakibatkan keadaan yang berbahaya karena keberadaannya sering kali tidak disadari dan kerap tidak menimbulkan keluhan yang berarti; sampai suatu waktu terjadi komplikasi jantung, otak, ginjal, mata, pembuluh darah, atau organ-organ vital lainnya. Namun demikian penyakit hipertensi sangat dipengaruhi oleh makanan yang dikonsumsi dan pekerjaan yang menguras aktivitas masyarakat sehingga mengurangi pola aktivitas yang baik untuk dilakukan. Pola aktivitas yang sehat dan makanan yang sehat merupakan pilihan tepat untuk menjaga diri terbebas dari hipertensi. Semuanya dilakukan secara terus menerus, tidak boleh temporer. Sekali kita lengah menjaga diri dengan tidak mengikuti pola aktivitas yang sehat, dipastikan kita akan mudah terkena hipertensi dan penyakit lainnya (Suoth, 2014).

Hipertensi timbul akibat adanya interaksi dari berbagai faktor risiko yaitu: umur, jenis kelamin, obesitas, alkohol, genetik, stres, asupan garam, merokok, pola aktivitas fisik, penyakit ginjal dan diabetes melitus. Oleh karena hipertensi timbul dari adanya interaksi dari berbagai faktor yang telah disebutkan, faktor mana yang lebih berpengaruh atau berperan terhadap timbulnya hipertensi tidak dapat 
diketahui dengan pasti (Anggara, 2013). Hipertensi salah satunya disebabkan oleh faktor gaya hidup modern, orang zaman sekarang lebih mengutamakan pekerjaan untuk mencapai kesuksesan. Kesibukan dan kerja keras serta tujuan-tujuan yang berat mengakibatkan timbulnya rasa stres dan tekanan yang tinggi. Hal tersebut diperkuat oleh penelitian Suoth (2014) yang menemukan bahwa terdapat hubungan bermakna antara gaya hidup dalam bentuk kemampuan mengatur stres dan kejadian hipertensi.

Perasaan tertekan membuat tekanan darah menjadi naik. Selain itu, orang yang sibuk juga tidak sempat untuk berolahraga. Akibatnya lemak dalam tubuh semakin banyak dan tertimbun yang dapat menghambat aliran darah. Pembuluh yang terhimpit oleh tumpukan lemak menjadikan tekanan darah menjadi tinggi. Inilah salah satu penyebab terjadinya hipertensi (Susilo, 2011).

Penyebab lain yang memicu terjadinya hipertensi adalah beban kerja. Dalam penelitian Sunarsih (2017) ditemukan bahwa terdapat hubungan antara beban kerja dengan kejadian hipertensi. Hal ini memperkuat adanya hubungan antara beban kerja dengan kejadian hipertensi.

Menurut Permendagri (2008), beban kerja adalah besaran pekerjaan yang harus dipikul oleh suatu jabatan/unit organisasi dan merupakan hasil kali antara volume kerja dan norma waktu. Menurut Dhania (2010, dalam Yo, 2015) beban kerja adalah sejumlah kegiatan yang membutuhkan keahlian dan harus dikerjakan dalam jangka waktu tertentu dalam bentuk fisik ataupun psikis. Beban kerja fisik meliputi besarnya aktivitas fisik yang dibutuhkan dalam melakukan tugas (contoh: mendorong, menarik, memutar, mengontrol, menjalankan dan lainnya). Beban kerja psikis yaitu besarnya aktivitas mental yang 
dibutuhkan untuk melihat, mengingat dan mencari, juga tekanan mental yang dialami karyawan selama bekerja serta pencapaian kerja karyawan.

Beban kerja ini merupakan sumber penyebab stres karyawan (Shah, 2011). Hampir semua orang di dalam kehidupan mereka mengalami stres berhubungan dengan pekerjaan mereka. Hal ini dapat dipengaruhi karena tuntutan kerja yang terlalu banyak (bekerja terlalu keras dan sering kerja lembur) dan jenis pekerjaan yang harus memberikan penilaian atas penampilan kerja bawahannya atau pekerjaan yang menuntut tanggung jawab bagi manusia. Apabila kondisi kerja cukup buruk, maka akan terjadi stres kerja dengan gejala fisikal, seperti tekanan darah tinggi, diare, obstipasi, dll (Cooper dalam Munandar, 2001).

Penelitian yang dilakukan oleh Parikh (2011) menunjukkan bahwa aktivitas fisik memiliki hubungan terhadap hipertensi, dan responden yang memiliki pekerjaan berat berisiko terjadi hipertensi sementara responden yang memiliki pekerjaan sedang mengalami hipertensi yang secara signifikan lebih rendah (nilai $\mathrm{z}=8.27, \mathrm{p}=0,001$ ) dibandingkan prevalensi di antara pekerja berat/menetap. Hal ini memperkuat asumsi bahwa pekerja yang mengerjakan pekerjaan berat memiliki risiko terjadi hipertensi lebih tinggi. Beberapa temuan yang sama yang diteliti di daerah perkotaan Chandigarh (dalam Parikh, 2011), ada $86.8 \%$ hipertensi berada di kelompok yang sering melakukan aktivitas fisik \& risiko terjadi hipertensi sebesar 35\% pada kelompok yang memiliki aktivitas kurang.

Perbedaan penelitian ini dengan penelitian sebelumnya adalah dari populasi yang digunakan. Contoh penelitian terdahulu antara lain penelitian Sunarsih (2017) dengan populasi pasien di poliklinik, penelitian Sinubu (2015) dengan populasi tenaga pengajar, dan 
penelitian Fernandez (2014) dengan populasi karyawan pabrik tekstil. Sementara dalam penelitian ini yang digunakan adalah populasi karyawan pabrik kimia yang tentunya beban kerja yang dimiliki berbeda dengan populasi lain.

Berdasarkan uraian tersebut bahwa suatu penyakit hipertensi mempunyai keterkaitan dengan status pekerjaan melalui beban kerja yang dilakukan, maka peneliti tertarik untuk meneliti tentang hubungan antara beban kerja dengan tekanan darah tinggi pada karyawan pabrik kimia di Karanganyar (PT. X). Penelitian ini dilakukan guna mengetahui penyebab kejadian hipertensi pada karyawan PT X yang disinyalir berasal dari beban kerja karyawan PT X.

\section{Hipertensi}

Tekanan darah tinggi (hipertensi) adalah keadaan dimana seseorang mengalami peningkatan tekanan darah di atas normal atau kronis (dalam waktu yang lama). Hipertensi merupakan kelainan yang sulit diketahui oleh tubuh kita sendiri. Hipertensi merupakan salah satu faktor risiko Penyakit Jantung Koroner (PJK). Jika dibiarkan tanpa perawatan yang tepat, hal itu dapat menimbulkan komplikasi yang berbahaya. Satu-satunya cara untuk mengetahui hipertensi adalah dengan mengukur tekanan darah kita secara teratur (Soeharto, 2004). Menurut WHO (dalam Dewi, 2012) secara umum seseorang dikatakan menderita hipertensi jika tekanan darah sistolik/diastoliknya melebihi 140/90 mmHg (normalnya 120/80 mmHg). Sistolik adalah tekanan darah pada saat jantung memompa darah ke dalam pembuluh nadi (saat jantung mengkerut). Diastolik adalah tekanan darah pada saat jantung mengembang dan menyedot darah kembali (pembuluh nadi mengempis kosong). Menurut Soeharto (2004), hipertensi berpengaruh terhadap 
hampir semua bagian tubuh, yang terpenting adalah darah, otak, ginjal, dan mata. Adapun komplikasi yang mungkin timbul tergantung pada berapa tinggi tekanan darah, berapa lama telah diderita, adanya faktorfaktor risiko yang lain, dan bagaimana keadaan tersebut dikelola atau ditangani.

\section{Faktor Terjadinya Hipertensi}

Kemunculan hipertensi dipengaruhi oleh faktor-faktor berikut. Faktor-faktor yang mempengaruhi hipertensi (Soeharto, 2004 \& Beevers, 2002):

1) Faktor keturunan atau gen

Kasus hipertensi esensial 70\% - 80\% diturunkan dari orang tuanya. Apabila riwayat hipertensi di dapat pada kedua orang tuanya maka dugaan hipertensi asensial lebih besar bagi seseorang yang kedua orang tuanya menderita hipertensi ataupun pada kembar monozygot (sel telur) dan salah satunya menderita hipertensi maka orang tersebut kemungkinan besar menderita hipertensi.

2) Faktor Berat badan (obesitas atau kegemukan)

Obesitas merupakan ciri khas penderita hipertensi. Walaupun belum diketahui secara pasti hubungan antara hipertensi dan obesitas, namun terbukti bahwa daya pompa jantung dan sirkulasi volume darah penderita obesitas dengan hipertensi lebih tinggi dari pada penderita hipertensi dengan berat badan normal.

3) Faktor Jenis Kelamin (Gender)

Hipertensi sering disebabkan oleh stres dalam kehidupan modern. Perempuan yang sebelumnya tidak mempunyai keluhan hipertensi dapat mengalaminya selama mengandung, terutama pada tiga bulan terakhir sebelum melahirkan. Bila dibiarkan, hal ini akan 
membahayakan baik ibu maupun bayinya. Perempuan yang mengkonsumsi pil kontrasepsi, mempunyai tingkat risiko yang lebih tinggi dibandingkan yang tidak mengkonsumsinya. Perempuan yang mengalami hipertensi dan memakai pil kontrasepsi jangan sekalisekali merokok. Hipertensi bagi perempuan sering terjadi setelah menopause.

4) Faktor Usia

Tekanan darah cenderung meningkat seiring bertambahnya usia, kemungkinan seseorang menderita hipertensi juga semakin besar. Pada umumnya penderita hipertensi adalah orang-orang yang berusia 40 tahun namun saat ini tidak menutup kemungkinan diderita oleh orang berusia muda (Soeharto, 2004). Boedhi Darmoejo dalam tulisannya yang dikumpulkan dari berbagai penelitian yang dilakukan di Indonesia menunjukan bahwa 1.8\% - 28.6\% penduduk yang berusia di atas 20 tahun adalah penderita hipertensi (Soeharto, 2004).

5) Pola Hidup

Tingkah laku seseorang mempunyai peranan yang penting terhadap timbulnya hipertensi. Mereka yang kelebihan berat badan di atas 30\%, mengkonsumsi minuman keras, dan tidak melakukan latihan mudah terkena hipertensi (Soeharto, 2004).

6) Garam Dapur ( $\mathrm{NaCl}$ )

Sodium adalah mineral yang esensial bagi kesehatan. Ini mengatur keseimbangan air di dalam sistem pembuluh darah. Sebagian sodium dalam diet datang dari makanan dalam bentuk garam dapur atau sodium chloride $(\mathrm{NaCl})$. Kecuali garam dapur, sumber yang lain adalah MSG (Mono Sodium Glutamate), soda pembuat roti. Pemasukan sodium mempengaruhi tingkat hipertensi. Mengkonsumsi garam menyebabkan haus dan mendorong kita 
minum. Hal ini meningkatkan volume darah di dalam tubuh, yang berarti jantung harus memompa lebih giat sehingga tekanan darah naik. Kenaikan ini berakibat pada ginjal yang harus menyaring lebih banyak garam dapur dan air. Karena masukan (input) harus sama dengan pengeluaran (output) dalam sistem pembuluh darah, jantung harus memompa lebih kuat dengan tekanan lebih tinggi (Soeharto, 2004).

\section{Beban Kerja}

Menurut Permendagri (2008), beban kerja adalah besaran pekerjaan yang harus dipikul oleh suatu jabatan/unit organisasi dan merupakan hasil kali antara volume kerja dan norma waktu. Terdapat faktor-faktor yang mempengaruhi beban kerja. Menurut Soleman (2011), faktor-faktor yang memengaruhi beban kerja adalah sebagai berikut:

1. Faktor eksternal

Faktor eksternal adalah beban kerja yang berasal dari luar tubuh pekerja, antara lain yaitu:

- Tugas (Task). Meliputi tugas bersifat seperti, stasiun kerja, tata ruang tempat kerja, kondisi ruang kerja, kondisi lingkungan kerja, sikap kerja, cara angkut, beban yang diangkat. Sedangkan tugas yang bersifat mental meliputi, tanggung jawab, kompleksitas pekerjaan, emosi pekerjaan dan sebagainya.

- Organisasi kerja. Meliputi lamanya waktu kerja, waktu istirahat, shift kerja, sistem kerja dan sebagainya. 
- Lingkungan kerja. Lingkungan kerja dapat memberikan beban tambahan yang meliputi, lingkungan kerja fisik, lingkungan kerja biologis dan lingkungan kerja psikologis.

2. Faktor internal

Faktor internal adalah faktor yang berasal dari dalam tubuh akibat dari reaksi beban kerja eksternal yang berpotensi sebagai stresor, meliputi faktor somatis (jenis kelamin, umur, ukuran tubuh, status gizi, kondisi kesehatan, dan sebagainya), dan faktor psikis (motivasi, persepsi, kepercayaan, keinginan, kepuasan, dan sebagainya).

\section{Dimensi Beban Kerja}

Hart dan Staveland (1988) membagi beban kerja fisik dan mental menjadi enam dimensi, ukuran beban kerja fisik meliputi physical demand, dan effort. Ukuran beban kerja mental meliputi mental demand, temporal demand, performance dan frustration level yaitu:

1. Physical demand, yaitu besarnya aktivitas fisik yang dibutuhkan dalam melakukan tugas (contoh: mendorong, menarik, memutar, mengontrol, menjalankan dan lainnya).

2. Effort, yaitu usaha yang dikeluarkan secara fisik dan mental yang dibutuhkan untuk mencapai level performansi karyawan.

3. Mental demand, yaitu besarnya aktivitas mental dan perseptual yang dibutuhkan untuk melihat, mengingat, dan mencari. Pekerjaan tersebut mudah atau sulit, sederhana atau kompleks, dan longgar atau ketat.

4. Temporal demand, yaitu jumlah tekanan yang berkaitan dengan waktu yang dirasakan selama pekerjaan berlangsung. Pekerjaan perlahan atau santai atau cepat, dan melelahkan 
5. Frustation level, yaitu seberapa tidak aman, putus asa, tersinggung, terganggu, dibandingkan dengan perasaan aman, puas, nyaman, dan kepuasan diri yang dirasakan.

6. Performance, yaitu seberapa besar keberhasilan seseorang di dalam pekerjaannya dan seberapa puas dengan hasil kerjanya.

\section{Metode}

Penelitian ini menggunakan desain penelitian kuantitatif dengan metode penelitian kuantitatif korelasional. Penelitian dengan pendekatan kuantiatif adalah penelitian yang data-datanya numerikal dan diolah dengan menggunakan metode statistik. Menurut Azwar (2010) penelitian korelasional bertujuan untuk menyelidiki sejauh mana variasi pada suatu variabel berkaitan dengan variabel pada satu atau lebih variabel lain, berdasarkan koefisien korelasi. Dari penelitian ini didapatkan informasi mengenai taraf hubungan yang terjadi, bukan mengenai ada tidaknya efek variabel satu terhadap variabel lain. Populasi dalam penelitian adalah seluruh karyawan PT X yang berjumlah 352 orang.

Teknik pengumpulan sampel menggunakan teknik cluster sampling yaitu cara pengambilan sampel berdasarkan cluster-cluster tertentu (Sugiyono, 2003). Dari populasi sejumlah 352 orang, terdapat 3 divisi, yaitu divisi CDIR, PLANT, dan COMERCIAL. Pada masing-masing divisi tersebut, terdapat departemen-departemen dengan total terdapat 18 departemen. Lalu dari 18 departemen tersebut diambil masingmasing $15 \%$ dari total jumlah karyawan pada departemen dan didapatkan jumlah total sampel sebanyak 52 sampel. Penelitian ini dilakukan dengan menggunakan pendekatan Cross Sectional dimana 
Amalia Nurazizah, Ading Pradana, Afani Nur Fauziyyah data dalam penelitian ini diambil dalam satu saat sekaligus (Kumar, 2011).

Dalam penelitian ini, skala yang digunakan adalah adapatasi dari skala beban kerja Prijayanti (2015) yang disusun berdasarkan aspekaspek dari pengukuran NASA-TLX oleh Hart \& Staveland (1988; dalam Prijayanti, 2015). Skala tersebut telah diuji coba dan menghasilkan indeks validitas T-Values sebesar 2,82 > 1,96 yang berarti validitas skala tersebut dikategorikan masih dapat dipercaya. Teknik analisis data menggunakan Uji Chi Square melalui SPSS untuk mencari korelasi antar variabel.

\section{Hasil}

\section{Analisa Univariat}

a. Jenis Kelamin

Tabel 1. Distribusi Responden Berdasarkan Jenis Kelamin

\begin{tabular}{|l|l|l|}
\hline Jenis Kelamin & $\mathbf{n}$ & $\mathbf{\%}$ \\
\hline Laki-laki & 48 & $92,3 \%$ \\
\hline Perempuan & 4 & $7,7 \%$ \\
\hline Total & $\mathbf{5 2}$ & $\mathbf{1 0 0 \%}$ \\
\hline
\end{tabular}

b. Tekanan Darah

Tabel 2. Distribusi Responden Berdasarkan Tekanan Darah

\begin{tabular}{|l|l|l|}
\hline Tekanan Darah & $\mathbf{n}$ & $\mathbf{\%}$ \\
\hline Normal & 42 & $80,77 \%$ \\
\hline Hipertensi & 10 & $19,23 \%$ \\
\hline
\end{tabular}


Amalia Nurazizah, Ading Pradana, Afani Nur Fauziyyah Total 52 $100 \%$

c. Beban Kerja

Tabel 3. Distribusi Responden Berdasarkan Beban Kerja

\begin{tabular}{|l|l|l|}
\hline Kategori Beban Kerja & $\mathbf{n}$ & $\mathbf{\%}$ \\
\hline Sangat Rendah & 0 & $0 \%$ \\
\hline Rendah & 0 & $0 \%$ \\
\hline Sedang & 42 & $80,77 \%$ \\
\hline Tinggi & 9 & $17,3 \%$ \\
\hline Sangat Tinggi & 1 & $1,92 \%$ \\
\hline Total & $\mathbf{5 2}$ & $\mathbf{1 0 0} \%$ \\
\hline
\end{tabular}

\section{Analisa Bivariat}

Tabel 4. Hubungan antara Beban Kerja dengan Tekanan Darah pada Karyawan PT X

Chi-Square Tests

\begin{tabular}{|l|c|c|c|}
\hline & Value & Df & \multicolumn{2}{|c|}{$\begin{array}{c}\text { Asymptotic } \\
\text { Significance (2-sided) }\end{array}$} \\
\hline $\begin{array}{l}\text { Pearson Chi- } \\
\text { Square }\end{array}$ & $.990^{\mathrm{a}}$ & 2 & .610 \\
Likelihood Ratio & 1.278 & 2 & .528 \\
Linear-by-Linear & .970 & 1 & .325 \\
Association & & & \\
N of Valid Cases & 52 & & \\
\hline
\end{tabular}

a. 3 cells (50.0\%) have expected count less than 5 . The minimum expected count is 21 . 
Pada tabel di atas didapatkan bahwa nilai signifikansi atau Asymp.

Sig. (2-sided) sebesar 0,610. Menurut Santoso (2014) pedoman pengambilan keputusan chi square dapat dilakukan dengan cara melihat nilai tabel output chi square dari hasil olah data SPSS. Dalam pengambilan keputusan, dapat dilakukan dengan membandingkan antara nilai Asymp. Sig. dengan batas kritis 0,05. Oleh karena Asymp. Sig. yang diperoleh $>0,05$, maka Ha pada penelitian ini ditolak, yang berarti tidak ada hubungan beban kerja terhadap tekanan darah tinggi (hipertensi) pada karyawan PT X.

\section{Pembahasan}

Hasil penelitian yang dilakukan di PT X menunjukkan bahwa distribusi responden berdasarkan jenis kelamin terbanyak adalah lakilaki. Kemudian distribusi responden berdasarkan tekanan darah terbanyak adalah tekanan darah normal dan beban kerja yang mereka alami masuk dalam kategori sedang. Berdasarkan hasil analisis data pada penelitian ini maka faktor beban kerja tidak mempunyai hubungan yang bermakna dengan tekanan darah tinggi (hipertensi) pada karyawan PT X.

Hasil dari penelitian ini tidak sejalan dengan penelitian yang dilakukan oleh Sunarsih \& Ilyas (2017) juga Sinubu (2015) yang menemukan bahwa ada hubungan yang bermakna antara beban kerja dengan terjadinya Hipertensi. Hal tersebut disebabkan oleh adanya perbedaan persentase karyawan dengan beban kerja yang signifikan. Dalam penelitian tersebut, terdapat lebih banyak karyawan dengan beban kerja berat daripada karyawan dengan beban kerja ringan. Sementara dalam penelitian ini, lebih sedikit karyawan dengan beban kerja berat-sangat berat daripada karyawan dengan beban kerja sedang- 
ringan. Selanjutnya, dari data tekanan darah dalam penelitian ini terdapat lebih banyak karyawan dengan tekanan darah normal. Sementara dalam penelitian tersebut, terdapat lebih banyak responden penderita hipertensi.

Pada penelitian ini, tidak terdapatnya hubungan antara hipertensi dengan beban kerja terjadi karena beberapa faktor diantaranya sedikitnya jumlah karyawan penderita hipertensi dan waktu pengambilan data yang dilakukan pada saat weekend dimana pada hari tersebut pekerjaan yang dilakukan karyawan lebih sedikit sehingga terjadi bias informasi ketika pengisian kuesioner dan berakibat pada jumlah karyawan dengan beban kerja berat-sangat berat yang sedikit.

Hal yang sama juga terjadi pada penelitian Darmadi, dkk. (2016) yang menemukan bahwa tidak ada hubungan signifikan antara beban kerja dengan Hipertensi. Dalam penelitian tersebut, terdapat lebih banyak karyawan dengan beban kerja berlebihan. Hal tersebut disebabkan oleh bias informasi beban kerja karena pada saat penelitian tersebut berlangsung bersamaan dengan waktu bagi PNS menyelesaikan tugas atau kegiatan yang berhubungan dengan pertanggungjawaban anggaran sebab waktu tersebut sudah mendekati akhir tenggat waktu penyelesaian tugas atau kegiatan untuk anggaran tahun 2013. Selain itu, kesamaan antara penelitian ini dengan penelitian Darmadi, dkk. (2016) yaitu lama kerja karyawan yang masih dalam batas normal (40 jam/minggu) dan adanya libur kerja bagi karyawan yaitu hari Sabtu dan Minggu sehingga karyawan mendapat cukup waktu untuk beristirahat di rumah atau rekreasi sehingga dapat menurunkan intensitas dari beban kerja karyawan di tempat kerja.

Selain itu terdapat pula faktor-faktor lain yang dapat menimbulkan hipertensi pada karyawan seperti yang disebutkan dalam penelitian 
Soeharto (2004), diantaranya faktor keturunan, berat badan, asupan $\mathrm{NaCl}$, juga usia karyawan.

\section{Simpulan}

Berdasarkan penelitian yang telah dilakukan di PT X dapat disimpulkan bahwa beban kerja yang dirasakan responden terbanyak pada kategori sedang, sementara tekanan darah responden terbanyak adalah pada tekanan darah normal. Hasil dari analisis data yang telah dilakukan menyebutkan bahwa tidak terdapat hubungan antara beban kerja dengan tekanan darah pada karyawan PT X. Tidak terdapatnya hubungan antara beban kerja dengan hipertensi pada penelitian ini disebabkan oleh sedikitnya jumlah penderita hipertensi juga pengambilan data yang dilakukan pada saat weekend sehingga terjadi bias informasi saat mengisi kuisioner yang berakibat pada sedikitnya beban kerja berat pada karyawan. Untuk peneliti selanjutnya disarankan untuk melakukan studi mengenai kebiasaan kerja karyawan terlebih dahulu guna mengetahui pola kerja karyawan sehingga hal bias informasi tidak terjadi. Selain itu terdapat beberapa faktor yang berpotensi untuk mengakibatkan terjadinya hipertensi pada karyawan faktor keturunan, berat badan, asupan $\mathrm{NaCl}$, juga usia karyawan yang belum diteliti pada penelitian ini. 
Amalia Nurazizah, Ading Pradana, Afani Nur Fauziyyah

Daftar Pustaka

Agustin, E. (2012). “Faktor Perilaku dan Hubungannya Dengan Kejadian Hypertensi." Public Health Journal, http//publichealthjournal.helpingpeopleideas.com. diakses tanggal 23 Oktober 2014.

Anggara, \& Prayitno, N. (2013). "Faktor-Faktor yang Berhubungan Dengan Tekanan Darah di Puskesmas Telaga Murni Cikarang Barat Tahun 2012." Jurnal Ilmiah Kesehatan, Vol. 5, No. 1.

Azwar, S. (2007). Sikap manusia. Teori dan Pengukurannya. Pustaka Pelajar, Yogyakarta.

Beevers D.G. (2002). Tekanan Darah. Jakarta: Dian Rakyat

Darmadi, Rudi., dkk. (2016). "Faktor-Faktor yang Berhubungan dengan Hipertensi pada Pegawai Negeri Sipil." Jurnal Public Health UM Pontianak.

Davis, Keith \& Newstrom, John W. (1985). Perilaku Dalam Organisasi. Jakarta: Erlangga.

Donnelly, Gibson \& ivancevich. (1993). Perilaku Struktur Proses. Jakarta: Erlangga.

Estiningsih. (2008). "Hubungan Indeks Massa Tubuh dan Faktor Lain dengan Kejadian Hipertensi Pada Kelompok Usia 18-44 Tahun di Kelurahan Suka Maju Depok." Skripsi.

Keputusan Menteri Pendayagunaan Aparatur Negara No: Kep/75/M.Pan/7/2004. Pedoman Perhitungan Kebutuhan

Pegawai Berdasarkan Beban Kerja dalam Rangka Penyusunan Formasi Pegawai Negeri Sipil.

Moekijat. (2004). Manajemen Tenaga Kerja dan Hubungan Kerja. Bandung: Pioner Jaya. 
Munandar. (2001). Stress dan Keselamatan Kerja, Psikologi Industri dan

Organisasi. Jakarta: Universitas Indonesia.

Permendagri No.12 Tahun 2008. Pedoman Analisis Beban Kerja di Lingkungan Departemen Dalam Negeri dan Pemerintah Daerah.

Prijayanti, Isnia. (2015). Pengaruh Beban Kerja dan Dukungan Sosial terhadap Burnout pada Karyawan PT. X. Skripsi. Universitas Islam Negeri Syarif Hidayatullah

S. Parikh, J., Choksi, D., V, Bala., (2011). "The Study of Epidemiology \& Determinents of Hypertension in Urban Health Training Centre (UHTC)." Gujarat Medical Journal Vol. 66, No.1.

Santoso, Singgih. (2014). Statistik Paametrik. Jakarta: PT. Elex Media Komputindo.

Sinubu, Rizky B., et al. (2015). "Hubungan Beban Kerja Dengan Kejadian Hipertensi Pada Tenaga Pengajar di SMA N 1 Amurang Kabupaten Minahasa Selatan." Jurnal Keperawatan UNSRAT, Vol. 3, No. 2 .

Soeharto, Iman. (2004). Serangan Jantung \& Sroke Hubungannya dengan lemak \& Kolesterol. Jakarta: PT. Gramedia Pustaka Utama

Soleman, Aminah. (2011). "Analisis Beban Kerja Ditinjau Dari Faktor Usia Dengan Pendekatan Recommended Weiht Limit." Jurnal Arika, Vol. 5, No. 2.

Sugiyono, M. P. P. (2007). Pendekatan Kuantitatif. Kualitatif, dan R\&D. Bandung: Alfabeta.

Sulistiani, Widi. (2005). “Analisis Faktor Resiko Yang Berkaitan Dengan Kejadian Hipertensi Pada Lansia di Wilayah Kerja Puskesmas Kroya I Kabupaten Cilacap Tahun 2005". Skripsi S1. Universitas Diponegoro Semarang 
Amalia Nurazizah, Ading Pradana, Afani Nur Fauziyyah

Sunarsih, Ilyas, Holidy. (2017). "Hubungan Beban Kerja Dengan Terjadinya Penyakit Hipertensi di Poliklinik Universitas Lampung". Jurnal Keperawatan, Vol. 13, No. 1.

Susilo, Y., Wulandary, A. (2011). Cara Jitu Mengatasi Hipertensi. Yogyakarta: C.V Andi Offset. 